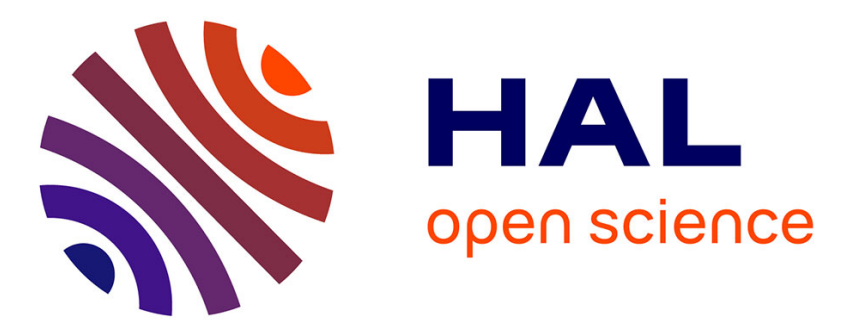

\title{
Spray-drying of protein/polysaccharide complexes: Dissociation of the effects of shearing and heating
} Jian Wang, Faydi Maoulida, Chedia Ben Amara, Sami Ghnimi, Nour-Eddine Chihib, Emilie Dumas, Adem Gharsallaoui

\section{- To cite this version:}

Jian Wang, Faydi Maoulida, Chedia Ben Amara, Sami Ghnimi, Nour-Eddine Chihib, et al.. Spraydrying of protein/polysaccharide complexes: Dissociation of the effects of shearing and heating. Food Chemistry, 2019, 297, pp.124943. 10.1016/j.foodchem.2019.06.010 . hal-02495854

\section{HAL Id: hal-02495854 \\ https://hal.science/hal-02495854}

Submitted on 25 Oct 2021

HAL is a multi-disciplinary open access archive for the deposit and dissemination of scientific research documents, whether they are published or not. The documents may come from teaching and research institutions in France or abroad, or from public or private research centers.
L'archive ouverte pluridisciplinaire HAL, est destinée au dépôt et à la diffusion de documents scientifiques de niveau recherche, publiés ou non, émanant des établissements d'enseignement et de recherche français ou étrangers, des laboratoires publics ou privés.

\section{(c)(1) $\$$}

Distributed under a Creative Commons Attribution - NonCommerciall 4.0 International 


\section{Spray-drying of protein/polysaccharide complexes: dissociation of the} effects of shearing and heating

Jian Wang ${ }^{\mathrm{a}}$, Faydi Maoulida ${ }^{\mathrm{a}}$, Chedia Ben Amara ${ }^{\mathrm{a}}$, Sami Ghnimi ${ }^{\mathrm{a}}$, Nour-Eddine Chihib ${ }^{\mathrm{b}}$ Emilie Dumas $^{\mathrm{a}}$, Adem Gharsallaoui ${ }^{\mathrm{a}}$

${ }^{a}$ Univ Lyon 1, ISARA Lyon, Laboratoire BioDyMIA, Equipe Mixte d'Accueil, n³733, IUT Lyon 1, technopole Alimentec, rue Henri de Boissieu, F-01000 Bourg en Bresse, France

${ }^{\mathrm{b}}$ CNRS, INRA, UMR 8207-UMET-PIHM, Université de Lille, 369 rue Jules Guesde, 59651 Villeneuve d'Ascq, France

Jian Wang : jian.wang@etu.univ-lyon1.fr

Faydi Maoulida : faydimaoulida@gmail.com

Chedia Ben Amara : benamarachedia@hotmail.fr

Sami Ghnimi : sghnimi@isara.fr

Nour-Eddine Chihib : nour-eddine.chihib@univ-lille.fr

Emilie Dumas : emilie.dumas@univ-lyon1.fr

\section{Corresponding author :}

Adem Gharsallaoui : adem.gharsallaoui@univ-lyon1.fr,

Tel: 0474455257 


\section{Abstract}

The aim of this study was to dissociate the effect of atomization from that of heating during the spray-drying of Low Methoxyl (LM) pectin/sodium caseinate complexes. The properties of these complexes were studied by measuring turbidity, particle size distribution, zeta-potential, as well as surface hydrophobicity of caseinate within the formed complexes. The results showed that the spraying step had a significant effect on the charge and the size of the complexes. In fact, the application of atomization resulted in the dissociation of caseinate/pectin aggregates especially for high pectin concentrations. Besides, the analysis of

31 the surface hydrophobicity of caseinate indicated that complexation with high concentrations of pectin is able to protect the structure of the protein against heat denaturation. This study allowed a better understanding of the influence of atomization and heat treatment (during the dehydration step) on the molecular interactions within caseinate/pectin complexes.

Keywords: LM pectin, sodium caseinate, atomization, complexes, thermal stability 


\section{Introduction}

In the past few decades, spray-drying technique has been widely used for encapsulation of food ingredients, which focus on protecting and controlling the release of active compounds. During this drying process, the solvent, that is most often water, will be rapidly evaporated, and the active compounds will be entrapped with encapsulating material (Gharsallaoui, Roudaut, Chambin, Voilley, \& Saurel, 2007). There are four stages involved in spray drying, namely (i) atomization of the feed solution, (ii) contact of spray with the hot gas, (iii) evaporation of moisture and (iv) particle separation. The loss of free water results in a reduction of water activity and thus extend the shelf life of food products. However, the spray-drying process is accompanied with thermo-mechanical stresses on the active compounds through exposure to high temperatures, distribution of air-water interfaces, shearing, and dehydration (Ben Amara, Eghbal, Degraeve, \& Gharsallaoui, 2016). During the spray-drying process, the pressure is mainly from two stages, the stage of atomization (distribution of air-water interfaces, shearing) and the stage of heating (high temperature, dehydration). Atomization is a very important and complex step (Foerster, Gengenbach, Woo, \& Selomulya, 2016; Wittner, Karbstein, \& Gaukel, 2018), which is same for other microencapsulation technologies like spray-cooling or spray-chilling. Heat treatment can easily change the structure of thermal sensitive material, especially for protein. This process may cause reversible or irreversible denaturation of proteins, which involves the disruption and possible destruction of both the secondary and tertiary structures. When proteins denatured, they can lose solubility to aggregation due to the exposure of hydrophobic groups and some bio-functional proteins (enzymes) can lose their biological function due to the loss of the active site.

The research concerning the formation of complexes between proteins and polysaccharides 
has received more and more attention (Devi, Sarmah, Khatun, \& Maji, 2017; Li \& de Vries, 2018). In fact, adding polysaccharides to form protein-polysaccharide complexes can somehow protect protein against denaturation during spray-drying process as shown in our previous works (Ben Amara, Eghbal, Degraeve, \& Gharsallaoui, 2016; Ormus, Oulahal, Noël, Degraeve, \& Gharsallaoui, 2015).

Sodium caseinate is a kind of milk proteins containing $\alpha_{\mathrm{s} 1^{-}}, \alpha_{\mathrm{s} 2^{-}}, \beta-$, and $\kappa$-caseins. These four proteins have a strong tendency to associate with each other to form supra-molecular aggregates (Surh, Decker, \& McClements, 2006). Pectin is a natural polysaccharide found as a component of cell walls in fruits and some roots, which is widely used in the food industry for its thickening and gelling properties. It is composed by a chain of $\alpha$-(1-4)-linked D-galacturonic acid. According to the degree of methyl esterification, pectin can be classified as high-methoxyl (HM) and low-methoxyl (LM) pectin. Compared to HM pectin, LM pectin requires less sugar to form gels, and can form gels in a wider range of $\mathrm{pH}$ (from 2.6 to 7.0). The system of pectin and caseinate is extensively investigated since over twenty years (Cheng \& McClements, 2016; Matia-Merino, Lau, \& Dickinson, 2004; Turgeon, Schmitt, \& Sanchez, 2007) and it was recently explored in our previous studies (Eghbal, Degraeve, Oulahal, Yarmand, Mousavi, \& Gharsallaoui, 2017; Eghbal, Yarmand, Mousavi, Degraeve, Oulahal, \& Gharsallaoui, 2016). According to these studies, complex coacervation of caseinate and LM pectin could happen at $\mathrm{pH}$ 3. At this $\mathrm{pH}$, positively-charged caseinate and negatively-charged pectin can form insoluble complexes due to electrostatic interactions. A greater understanding of how caseinate interact with pectin is essential to control structure, functionality and applicability of this system.

In this study, we separated the atomization process and heating process in spray-drying by dissociating the atomizer from spray-drier and replacing heating process with water bath heat 

treatment. To the best of our knowledge, the separate effects of atomization and heating steps

84 during spray-drying on the properties of protein/polysaccharide complexes were not reported in 85 literature. Through testing the physicochemical properties of caseinate/pectin complexes before 86 and after atomization and heat treatment, we hoped to investigate the effect of atomization and 87 heat treatment on the formation of protein/polysaccharide complexes. 


\section{Materials and methods}

\subsection{Materials}

LM pectin (Unipectine ${ }^{\mathrm{TM}}$ OF 305 C SB) was purchased from Cargill (Baupte, France). The degree of esterification was from $22 \%$ to $28 \%$ and the degree of acetylation was from $20 \%$ to 23\%. Sodium caseinate was purchased from Fisher Scientific (United Kingdom). Protein content in sodium caseinate determined by the Kjeldahl method was $93.20 \%$ (nitrogen conversion factor $\mathrm{N}=6.38)$. Analytical grade imidazole $\left(\mathrm{C}_{3} \mathrm{H}_{4} \mathrm{~N}_{2}\right)$, acetic acid, sodium hydroxide $(\mathrm{NaOH})$, hydrochloric acid ( $\mathrm{HCl})$, 8-Anilino-1-naphthalenesulfonic acid (ANS) were purchased from Sigma-Aldrich Chimie (St Quentin Fallavier, France).

\subsection{Solution preparation}

Imidazole-acetate buffer solutions $(5 \mathrm{mM})$ were prepared by dispersing imidazole and acetic acid into distilled water and then adjusting the $\mathrm{pH}$ to 3.0. The stock solutions were prepared by dispersing LM pectin and sodium caseinate powders to unadjusted imidazole-acetate buffer and stirring for at least $2 \mathrm{~h}$ at room temperature, and then adjusting the $\mathrm{pH}$ to 3.0. The $\mathrm{pH}$ was adjusted by using $\mathrm{HCl}(0.1$ or $1.0 \mathrm{M})$ or $\mathrm{NaOH}(0.1$ or $1.0 \mathrm{M})$. Complexes solutions were prepared by mixing the stock solutions and then diluted to the desired concentration by imidazole-acetate buffer ( $\mathrm{pH}$ 3.0). The final sodium caseinate concentration was constant at 5.0 $\mathrm{g} / \mathrm{L}$, and the $\mathrm{LM}$ pectin concentration was $0.5,2.0$ and $6.0 \mathrm{~g} / \mathrm{L}$. After mixing, the complexes solutions were stirred for at least $2 \mathrm{~h}$ at room temperature and the $\mathrm{pH}$ was checked again.

\subsection{The atomization process}

The atomizer (Mini spray-dryer B-290) was manufactured by BUCHI (Switzerland). The atomizer nozzle was disassembled to prepare the complex solutions after atomization. The 
nozzle consists of three inputs: an air inlet and two inputs for the liquid as well as an outlet. An atomizer pump that set at a flowrate of $0.5 \mathrm{~L} / \mathrm{h}$ was used to feed the nozzle with the previously prepared complex solutions. In order to study the effect of the shearing applied during the spray-drying process, the sodium caseinate/LM pectin complex mixtures were subsequently sprayed at a rate of $0.5 \mathrm{~L} / \mathrm{h}$ through the nozzle of the atomizer (complex after spraying) and recovered in containers until the tests are carried out. All the atomization experiments were carried at room temperature, the suspensions of complexes before and after spraying were also maintained at room temperature.

\subsection{Heat treatment}

During spray-drying, the suspensions of complexes are exposed to high temperatures during a very short time, which makes it possible to dry the sprayed micro-droplets rapidly. For separately studying the effect of the heat treatment, the various mixtures obtained (in $10 \mathrm{~mL}$ tubes) were heated in a water bath at $80{ }^{\circ} \mathrm{C}$ for time intervals set at $1 \mathrm{~min}(\mathrm{~T} 1), 2 \mathrm{~min}(\mathrm{~T} 2), 3 \mathrm{~min}$ (T3) and 4 min (T4). Complexes that underwent heat treatment were compared with unheated complexes (T0).

\subsection{Turbidity measurement}

The turbidity of all complexes suspensions at $\mathrm{pH} 3$ were measured by using a UV/Vis spectrophotometer (Jenway 3705, Villepinte, France) at $600 \mathrm{~nm}$ in plastic cuvettes $(1 \mathrm{~cm}$ path length). Each suspension was diluted 3 to 6 times with imidazole-acetate buffer at pH 3 until the optical density value of each diluted suspension was less than 1.5 . The solution of $(5.0 \mathrm{~g} / \mathrm{L})$ sodium caseinate was used as a control during the measurements, and every suspension was analyzed at least three times.

\subsection{Particle size distribution}


Particle size distributions of sodium caseinate/LM pectin complexes were assessed by a

laser diffraction instrument (Mastersizer 3000, Malvern Instruments, Malvern, UK). To avoid multiple scattering effects, the complexes were injected into the measurement chamber where it was diluted with imidazole-acetate buffer $(5 \mathrm{mM}$; $\mathrm{pH} 3)$ prior to the measurements. The complexes were continuously stirred throughout the measurement to ensure the samples were homogeneous. The volume mean particle diameter $\left(\mathrm{D}_{43}\right)$ was calculated by the software from the three injections of three separate samples with five readings per sample.

\subsection{Zeta potential measurement}

The electric charges ( $\zeta$-potential) of sodium caseinate/LM pectin complexes were determined using a Zetasizer Nano ZS90 (Malvern Instruments, Malvern, UK). If necessary, the samples were diluted with $\mathrm{pH} 3$ imidazole-acetate buffer. The mean $\zeta$-potential $(\mathrm{ZP})$ values $( \pm \mathrm{SD}$ (standard deviation)) were obtained from the instrument, standard deviation of measurements that are repeated three times for each suspension.

\subsection{Measurement of surface hydrophobicity}

For the surface hydrophobicity study, the 8-anilino-1-naphthalenesulfonic acid (ANS) fluorescent probe was used (Bi, Tang, Gao, Jia, \& Lv, 2016). For each suspension studied, increasing volumes of the probe $(20 \mathrm{mg} / \mathrm{L})$ ranging from 10 to $30 \mu \mathrm{L}$ were added to $4.0 \mathrm{ml}$ of the suspension. The maximum fluorescence intensity due to the binding of the ANS molecules to the hydrophobic sites of the protein was measured by carrying out a scanning of the wavelength between $420 \mathrm{~nm}$ and $650 \mathrm{~nm}$ for an excitation wavelength of $380 \mathrm{~nm}$. The excitation and emission bandwidths were set at $5.0 \mathrm{~nm}$. The scan rate was $500 \mathrm{~nm} / \mathrm{min}$. Fluorescence intensity measurements were performed with a LS 55 spectrofluorometer (PerkinElmer, Courtaboeuf, 
France). All measurements were performed at room temperature using a quartz cuvette (4 faces,

$1571 \mathrm{~cm}$ path length). The addition of the probe was achieved until no increase of the fluorescence 158 intensity was observed. The maximum fluorescence intensity was plotted against the 159 concentration of ANS. The initial slope of the curve of maximum fluorescence intensity 160 (arbitrary unit, U.A) versus ANS concentration (mg/L) was calculated and used as an index of 161 surface hydrophobicity $\left(\mathrm{S}_{0}\right)$. For each suspension, the test was repeated three times.

\subsection{Statistical analysis}

All assays were measured at least in triplicate. Means and standard deviations were calculated and differences between means were determined with the Least Significant Difference (LSD) test at $\mathrm{p}<0.05$ significance level (Statgraphics Centurion XV). 


\section{Results and discussion}

\subsection{Effect of atomization on the properties of caseinate/pectin complexes}

The effect of atomization (shearing) on the properties of caseinate/pectin complexes was studied at three different ratios (sodium caseinate concentration kept constant: $5.0 \mathrm{~g} / \mathrm{L}$; LM pectin concentration changed: $0.5,2.0$ or $6.0 \mathrm{~g} / \mathrm{L})$. Before atomization, the turbidity of complexes increased (Fig. 1a) with increasing pectin concentration while the average size reached a peak (Fig. 1b). This indicated that, with addition of pectin, caseinate could combine more and more pectin to form complexes leading to a growing size until a pectin concentration of $2 \mathrm{~g} / \mathrm{L}$ and turbidity increase. When pectin amount continued to increase, the particle size decreased leading to the formation of numerous small complexes resulting in the still increase of turbidity.

As shown in Fig. 2a, the $\zeta$-potential values of complexes changed from positive to negative with increasing pectin concentration, due to the constant amount of positively charged caseinate molecules neutralized by the increase amount of negatively-charged pectin. At the low $(0.5 \mathrm{~g} / \mathrm{L})$ and high $(6.0 \mathrm{~g} / \mathrm{L})$ concentrations of pectin, the caseinate/pectin complexes were highly charged, and at intermediate $(2.0 \mathrm{~g} / \mathrm{L})$ concentration of pectin, the complexes were more neutrally charged. These results also confirmed that the size decrease at high $(6.0 \mathrm{~g} / \mathrm{L})$ concentration of pectin was due to electrostatic repulsions. There was a slight decrease of the protein hydrophobicity only at high pectin concentration (6.0 g/L) (Fig. 2b), which means that hydrophobic sites of caseinate would be masked by the pectin chains.

After atomization, the turbidity of complexes was almost constant at low $(0.5 \mathrm{~g} / \mathrm{L})$ and intermediate $(2.0 \mathrm{~g} / \mathrm{L})$ concentrations of pectin. At high concentration $(6.0 \mathrm{~g} / \mathrm{L})$ of pectin, the turbidity of complexes significantly decreased $(p<0.05)$ after atomization (Fig. 1a). The average 
size of complexes significantly decreased $(p<0.05)$ at all the 3 tested ratios (Fig. 1b), which is in agreement with other published studies (Serfert, Schröder, Mescher, Laackmann, Rätzke, Shaikh, et al., 2013). The partial dissociation of complexes was due to shear forces during their passage in the nozzle and an increase in their overall charge favoring electrostatic repulsions, especially at high concentration $(6.0 \mathrm{~g} / \mathrm{L})$ of pectin (Fig. 2a). In addition, there was a significant increase of the hydrophobicity $\mathrm{S}_{0}$ (particularly at $2.0 \mathrm{~g} / \mathrm{L}$ and $6.0 \mathrm{~g} / \mathrm{L}$ of pectin), which could indicate molecular rearrangements and unfolding of the structure of the protein caused by exposure of hydrophobic sites (Fig. 2b).

\subsection{Effect of heat treatment on the properties of caseinate/pectin complexes}

Heat treatment had a significant effect on the turbidity and the size of the complexes (Fig. 3). With the increase of the heat treatment time, the turbidity value of complexes increased $(p<0.05)$ from $0.98 \pm 0.05$ to $2.87 \pm 0.28 \mathrm{~cm}^{-1}$ at the lower concentration of pectin. It was almost constant $\left(\sim 4.22 \mathrm{~cm}^{-1}\right)$ at the intermediate concentration of pectin. However, at the higher concentration of pectin, the turbidity value of complexes increased $(p<0.05)$ from $5.29 \pm 0.09 \mathrm{~cm}^{-1}$ to $6.78 \pm$ $0.04 \mathrm{~cm}^{-1}$ until the $4^{\text {th }}$ min where we had a decrease up to $6.05 \pm 0.17 \mathrm{~cm}^{-1}$ (Fig. 3a).

As shown in Fig. 3b, the size of complexes formed at low concentration of pectin $(0.5 \mathrm{~g} / \mathrm{L})$ was constant as a function of heating time $(55.77 \pm 4.53 \mu \mathrm{m})$. Combined with the increased turbidity (Fig. 3a), it can be concluded that heat treatment caused the formation of more numerous particles which had the same size as the caseinate/pectin complexes at low pectin concentration. At intermediate concentration of pectin $(2.0 \mathrm{~g} / \mathrm{L})$, the size increased from $264.17 \pm$ 26.36 to $380.80 \pm 35.05 \mu \mathrm{m}(p<0.05)$ with increase of heat treatment time. Combined with the stable turbidity (Fig. 3a), it clarified that heat treatment caused the aggregation of complexes at this pectin concentration. The most interest part was the significant decrease $(p<0.05)$ of 
particle size from $220.46 \pm 38.08$ to $104.16 \pm 29.62 \mu \mathrm{m}$ at high concentration of pectin $(6.0 \mathrm{~g} / \mathrm{L})$,

214 with increase of heating time. This result indicated that heat treatment caused dissociation of aggregates. This also explained the decrease of turbidity after 4 min of heating time (Fig. 3a). High concentration of LM pectin may have induced bridging flocculation of protein aggregates (Jones, Lesmes, Dubin, \& McClements, 2010). It can be assumed that, after heating treatment, bridging flocculation was suppressed.

At low concentration of pectin, slight decrease $(p<0.05)$ in $\zeta$-potential (Fig. 4a) and increase in surface hydrophobicity (Fig. 4b) indicated that the structure of complexes changed. Anionic groups of pectin and hydrophobic sites in caseinate molecules could be exposed following heat treatment. The change of the electrostatic charge from positive to negative and a slight increase in the hydrophobicity at intermediate concentrations of pectin indicated that the molecular rearrangement allowed to "protect" the protein from heat denaturation. At high concentration of pectin, surface hydrophobicity was almost constant as the increasing time, which confirmed the protective effect of pectin against heat treatment. According to Jones, Decker and McClements (2010), the ability of LM pectin to increase the thermal denaturation temperature may be due to differences in the electrostatic interactions between carboxyl groups and subsequently heated. Combined effect of atomization and heat treatment was evaluated by measuring the properties of atomized complexes treated by heating at $80{ }^{\circ} \mathrm{C}$ water bath for 0 to 4 $\min$. 
$(0.5 \mathrm{~g} / \mathrm{L})$, the turbidity of atomized complexes slightly increased $(p<0.05)$ from $1.05 \pm 0.17$

$\mathrm{cm}^{-1}$ to $2.08 \pm 0.03 \mathrm{~cm}^{-1}$ and the particle size was constant $(44.52 \pm 5.73 \mu \mathrm{m})$. The increase in number of particles could be due to the aggregation of free or partially complexed caseinate molecules. Compared to the properties of caseinate/pectin complexes directly treated by heating without atomization at low pectin concentration (Fig. 3), the atomized complexes had a smaller size and the turbidity of atomized complexes as function of heat treatment duration increased more slightly.

At intermediate pectin concentration $(2.0 \mathrm{~g} / \mathrm{L})$, with the increase of heating duration, compared to the stable turbidity of caseinate/pectin complexes without atomization (Fig. 3a), heat treatment caused the slight decrease $(p<0.05)$ in turbidity of atomized complexes from 4.42 $\pm 1.00 \mathrm{~cm}^{-1}$ to $2.93 \pm 0.12 \mathrm{~cm}^{-1}$ (Fig. $\left.5 \mathrm{a}\right)$, and significant increase $(p<0.05)$ in particle size from $115.70 \pm 34.17$ to $379.22 \pm 24.72 \mu \mathrm{m}$ (Fig. 5b). Thus, we can assume that the association between small complexes could be accentuated by electrostatic charge neutralization (Fig. 5c). Compared to the caseinate/pectin complexes directly treated by heating without atomization, atomized complexes formed at intermediate pectin concentration were more sensitive to heat treatment.

Atomized complexes formed at high pectin concentration $(6.0 \mathrm{~g} / \mathrm{L})$ showed a constant particle size $(32.61 \pm 4.62 \mu \mathrm{m})$ and an increased turbidity from $3.85 \pm 0.06 \mathrm{~cm}^{-1}$ to $8.97 \pm 0.97$ $\mathrm{cm}^{-1}$ with the increase of heat treatment duration (Fig. 5). Similar results were also found in our previous research (Amara, Eghbal, Degraeve, \& Gharsallaoui, 2016). The increase of turbidity could be due to thermal dissociation of aggregates, which was already deconstructed by shearing, and formation of new complexes with free pectin chains. Highly negatively charged complexes could be protected from aggregation by electrostatic repulsions (Fig. 5c). 


\section{Conclusions}

In this study, caseinate/pectin complexes were prepared at $\mathrm{pH} 3$ at three different

caseinate/pectin ratios. To evaluate the separate effect of mechanical and thermal steps on the complexes during the spray-drying process, atomization and heat treatment were dissociated and applied to the caseinate/pectin complexes. The properties like turbidity, $\zeta$-potential, particle size and surface hydrophobicity of complexes were measured.

The results indicated that atomization caused dissociation of aggregates into smaller size complexes at all pectin concentrations. At low concentration of pectin, heat treatment caused the aggregation of excess caseinate. At intermediate concentration of pectin, heat treatment intensified aggregation of complexes. At high concentration of pectin, heat treatment favored the dissociation of the aggregates. Complexes after atomization were more sensitive to heat treatment, but a high concentration of pectin could protect the complexes against heat aggregation. These results could help to develop new delivery systems based on spray-dried protein/polysaccharide complexes.

\section{Acknowledgements}

Jian Wang greatly thanks Chinese Scholarship Council for support. The authors are indebted to Conseil Départemental de l'Ain and Bourg en Bresse Agglomération for their financial support. 


\section{REFERENCES}

Ben Amara, C. B., Eghbal, N., Degraeve, P., \& Gharsallaoui, A. (2016). Using complex coacervation for lysozyme encapsulation by spray-drying. Journal of Food Engineering, 183, 50-57.

Bi, H., Tang, L., Gao, X., Jia, J., \& Lv, H. (2016). Spectroscopic analysis on the binding interaction between tetracycline hydrochloride and bovine proteins $\beta$-casein, $\alpha$-lactalbumin. Journal of Luminescence, 178, 72-83.

Cheng, W., \& McClements, D. J. (2016). Biopolymer-stabilized conjugated linoleic acid (CLA) oil-in-water emulsions: Impact of electrostatic interactions on formation and stability of pectin-caseinate-coated lipid droplets. Colloids and Surfaces A: Physicochemical and Engineering Aspects, 511, 172-179.

Devi, N., Sarmah, M., Khatun, B., \& Maji, T. K. (2017). Encapsulation of active ingredients in polysaccharide-protein complex coacervates. Advances in Colloid and Interface Science, 239, 136-145.

Eghbal, N., Degraeve, P., Oulahal, N., Yarmand, M. S., Mousavi, M. E., \& Gharsallaoui, A. (2017). Low methoxyl pectin/sodium caseinate interactions and composite film formation at neutral pH. Food Hydrocolloids, 69, 132-140.

Eghbal, N., Yarmand, M. S., Mousavi, M., Degraeve, P., Oulahal, N., \& Gharsallaoui, A. (2016). Complex coacervation for the development of composite edible films based on LM pectin and sodium caseinate. Carbohydrate Polymers, 151, 947-956.

Foerster, M., Gengenbach, T., Woo, M. W., \& Selomulya, C. (2016). The impact of atomization on the surface composition of spray-dried milk droplets. Colloids Surf B Biointerfaces, $140,460-471$.

Gharsallaoui, A., Roudaut, G., Chambin, O., Voilley, A., \& Saurel, R. (2007). Applications of spray-drying in microencapsulation of food ingredients: An overview. Food Research International, 40(9), 1107-1121.

Li, X., \& de Vries, R. (2018). Interfacial stabilization using complexes of plant proteins and polysaccharides. Current Opinion in Food Science, 21, 51-56. 
Jones, O., Decker, E. A., \& McClements, D. J. (2010). Thermal analysis of $\beta$-lactoglobulin complexes with pectins or carrageenan for production of stable biopolymer particles. Food Hydrocolloids, 24(2-3), 239-248.

Jones, O. G., Lesmes, U., Dubin, P., \& McClements, D. J. (2010). Effect of polysaccharide charge on formation and properties of biopolymer nanoparticles created by heat treatment of $\beta$-lactoglobulin-pectin complexes. Food Hydrocolloids, 24(4), 374-383.

Matia-Merino, L., Lau, K., \& Dickinson, E. (2004). Effects of low-methoxyl amidated pectin and ionic calcium on rheology and microstructure of acid-induced sodium caseinate gels. Food Hydrocolloids, 18(2), 271-281.

Ormus, S., Oulahal, N., Noël, C., Degraeve, P., \& Gharsallaoui, A. (2015). Effect of low methoxyl (LM) pectin complexation on the thermal and proteolytic inactivation of lysozyme: A kinetic study. Food Hydrocolloids, 43, 812-818.

Serfert, Y., Schröder, J., Mescher, A., Laackmann, J., Rätzke, K., Shaikh, M. Q., Gaukel, V., Moritz, H. U., Schuchmann, H. P., Walzel, P., Drusch, S., \& Schwarz, K. (2013). Spray drying behaviour and functionality of emulsions with $\beta$-lactoglobulin/pectin interfacial complexes. Food Hydrocolloids, 31(2), 438-445.

Surh, J., Decker, E., \& McClements, D. (2006). Influence of $\mathrm{pH}$ and pectin type on properties and stability of sodium-caseinate stabilized oil-in-water emulsions. Food Hydrocolloids, 20(5), 607-618.

Turgeon, S. L., Schmitt, C., \& Sanchez, C. (2007). Protein-polysaccharide complexes and coacervates. Current Opinion in Colloid \& Interface Science, 12(4-5), 166-178.

Wittner, M. O., Karbstein, H. P., \& Gaukel, V. (2018). Spray performance and steadiness of an effervescent atomizer and an air-core-liquid-ring atomizer for application in spray drying processes of highly concentrated feeds. Chemical Engineering and Processing - Process Intensification, 128, 96-102. 


\section{Figure Captions}

Fig. 1. Effect of atomization on turbidity (a) and particle size (b) of caseinate/pectin complexes at three different concentrations of pectin (the concentration of caseinate was kept constant at 5.0 $\mathrm{g} / \mathrm{L}$; pectin concentrations was varied from 0.5 to $6.0 \mathrm{~g} / \mathrm{L} ; \mathrm{pH} 3)$.

Fig. 2. Effect of atomization on $\zeta$-potential (a) and surface hydrophobicity (b) profiles of caseinate/pectin complexes at three different concentrations of pectin (the concentration of caseinate was kept constant at $5.0 \mathrm{~g} / \mathrm{L}$; pectin concentrations was varied from 0.5 to $6.0 \mathrm{~g} / \mathrm{L} ; \mathrm{pH}$ $3)$.

Fig. 3. Turbidity (a) and particle size (b) of caseinate/pectin complexes at three different concentrations of pectin as function of heat treatment duration from 0 to $4 \mathrm{~min}$ at $80{ }^{\circ} \mathrm{C}$ (T0: unheated control, T1: $1 \mathrm{~min}, \mathbf{T 2}: 2 \mathrm{~min}, \mathbf{T 3}: 3 \mathrm{~min}, \mathbf{T 4}: 4 \mathrm{~min}$; the concentration of caseinate was kept constant at $5.0 \mathrm{~g} / \mathrm{L}$; pectin concentrations was varied from 0.5 to $6.0 \mathrm{~g} / \mathrm{L} ; \mathrm{pH} 3$ ).

Fig. 4. $\zeta$-potential (a) and surface hydrophobicity (b) of caseinate/pectin complexes at three different concentrations of pectin as function of heat treatment duration from 0 to 4 min at $80{ }^{\circ} \mathrm{C}$ (T0: unheated control, T1: $1 \mathrm{~min}, \mathbf{T 2}: 2 \mathrm{~min}, \mathbf{T 3}: 3 \mathrm{~min}, \mathbf{T 4}: 4 \mathrm{~min}$; the concentration of caseinate was kept constant at $5.0 \mathrm{~g} / \mathrm{L}$; pectin concentrations was varied from 0.5 to $6.0 \mathrm{~g} / \mathrm{L} ; \mathrm{pH}$ $3)$.

Fig. 5. Combined effect of atomization and heat treatment $\left(80^{\circ} \mathrm{C}\right)$ on turbidity (a), particle size (b) and $\zeta$-potential (c) of caseinate/pectin complexes at three different concentrations of pectin (T0: unheated control, T1: $1 \mathrm{~min}, \mathbf{T 2}: 2 \mathrm{~min}, \mathbf{T 3}: 3 \mathrm{~min}, \mathbf{T 4}: 4 \mathrm{~min}$; the concentration of 

$3)$. 
Fig. 1

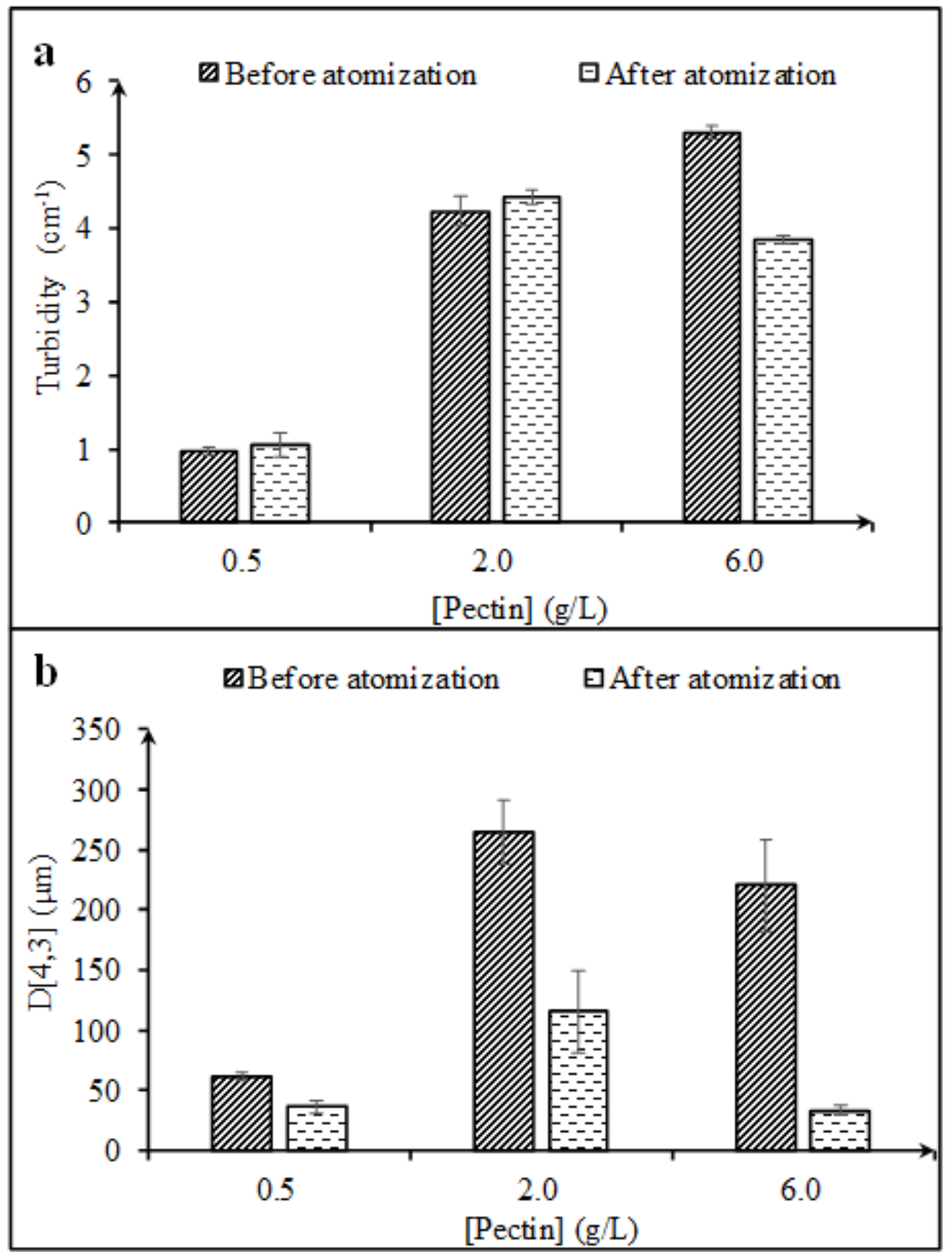


Fig. 2

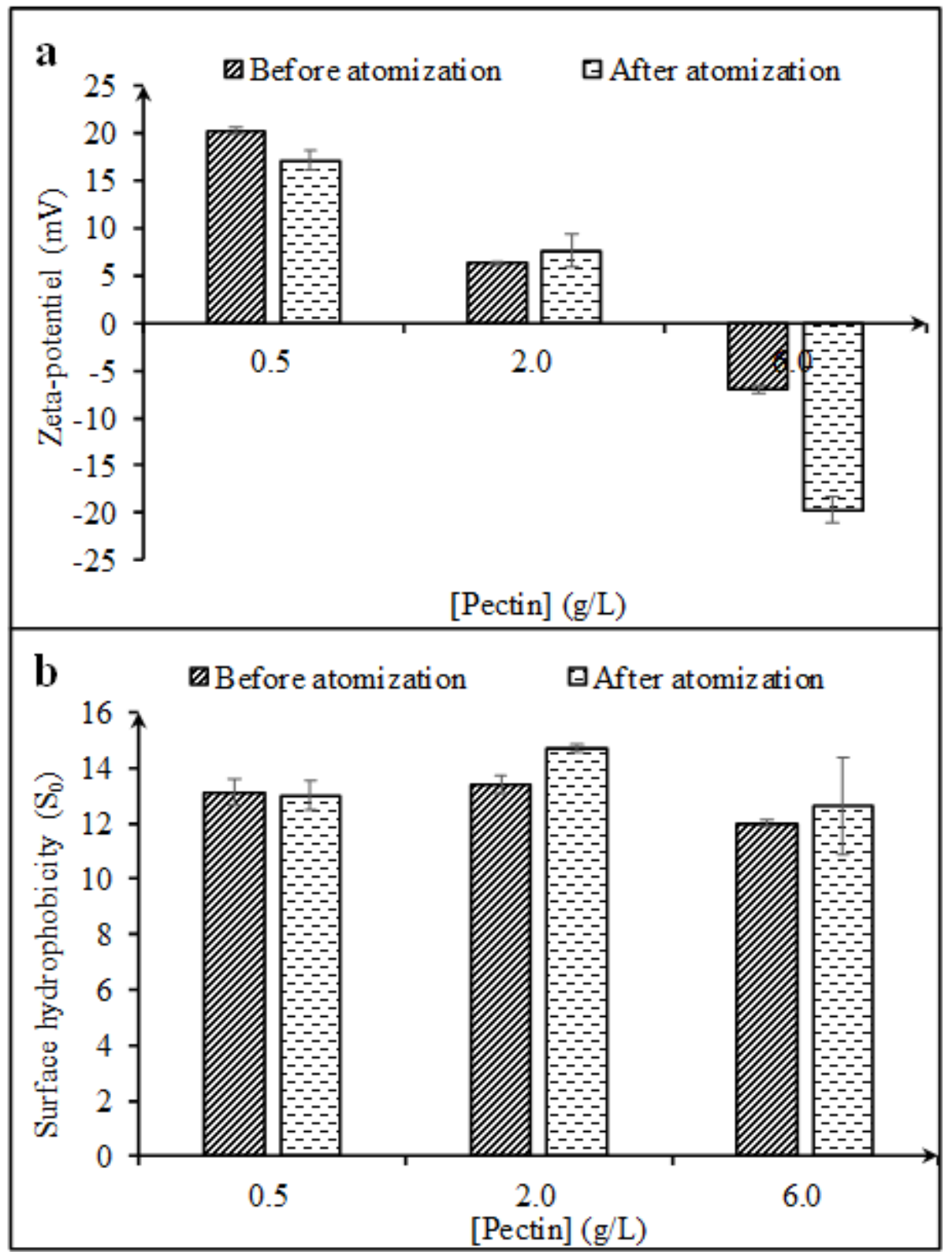


Fig. 3

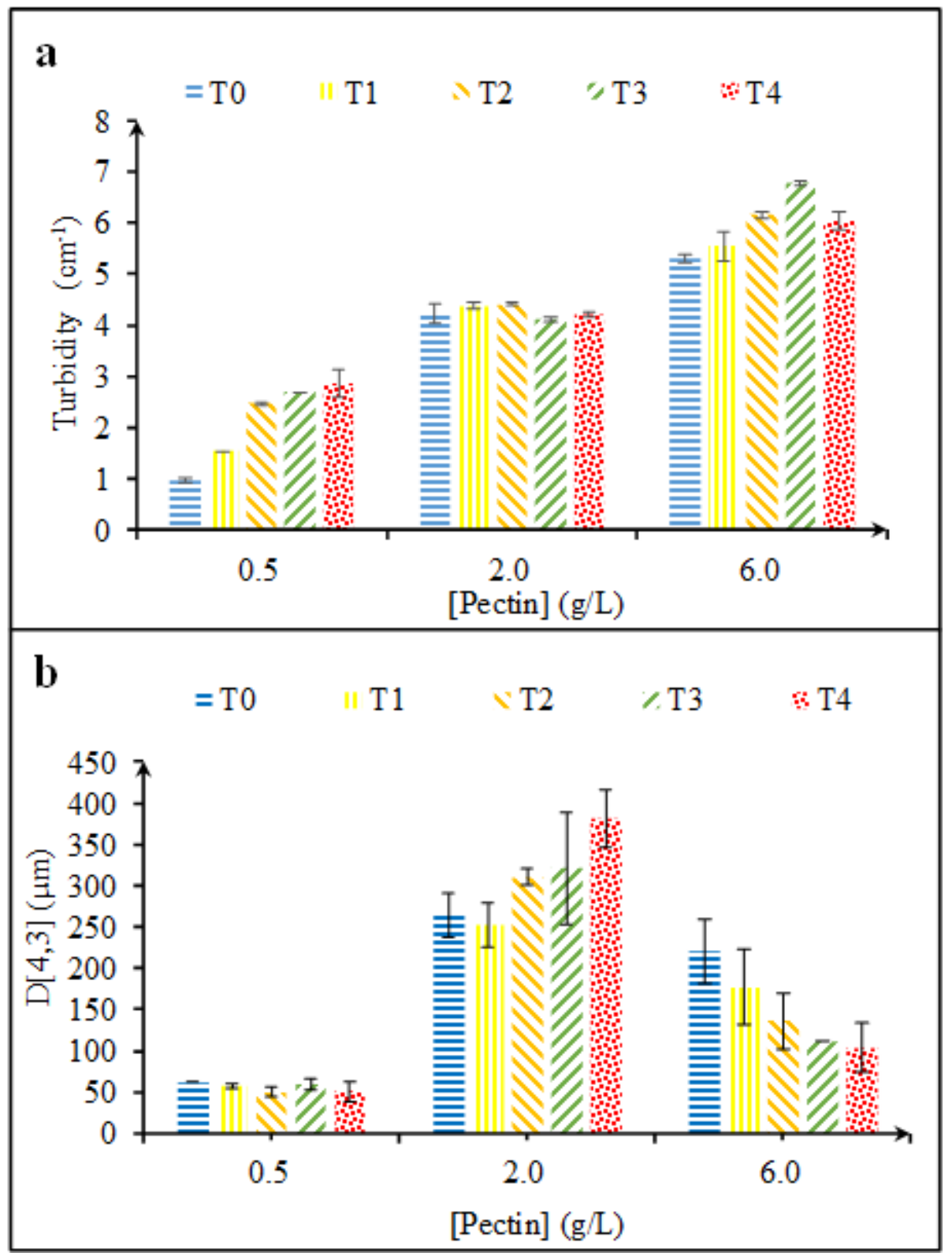


Fig. 4

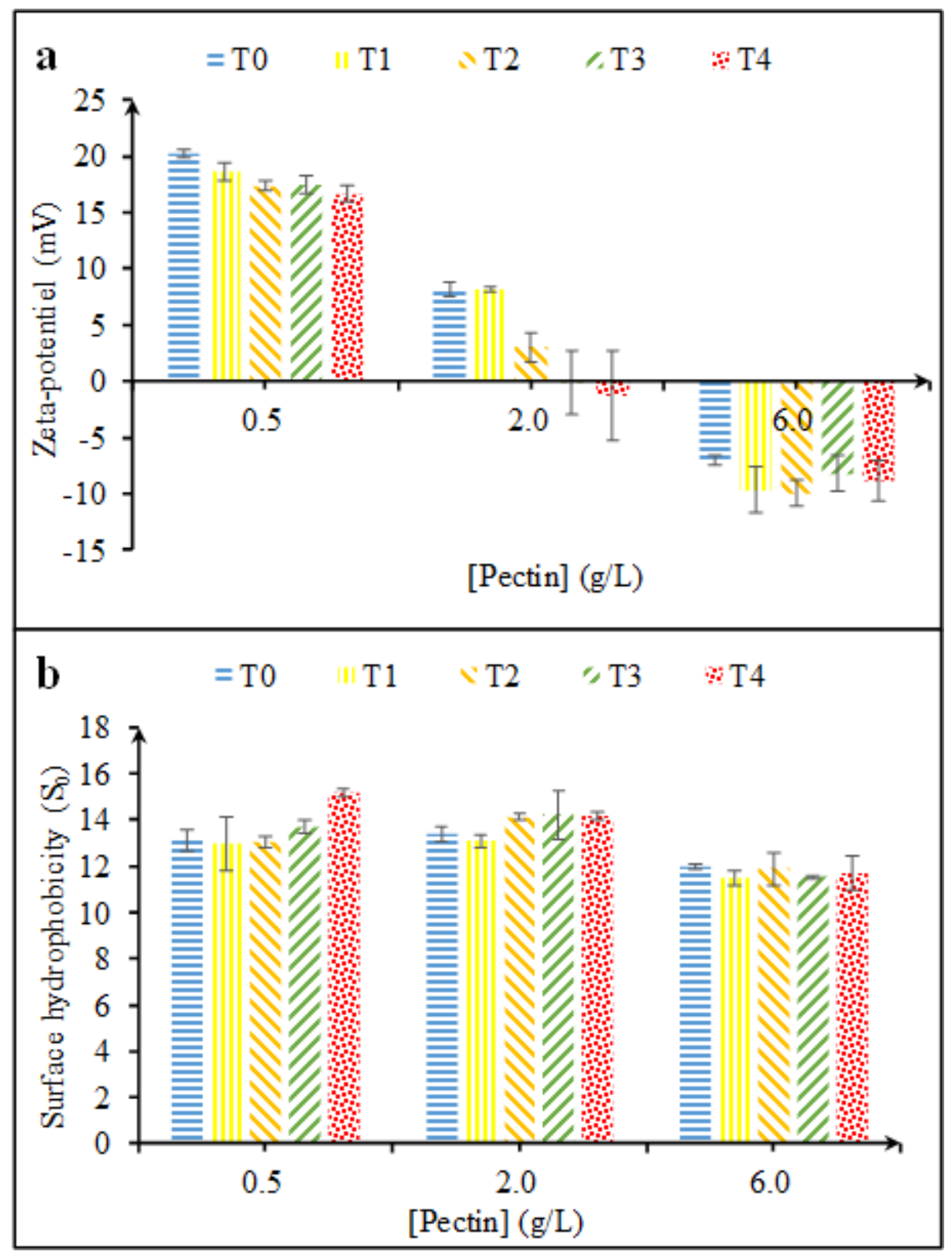


Fig. 5
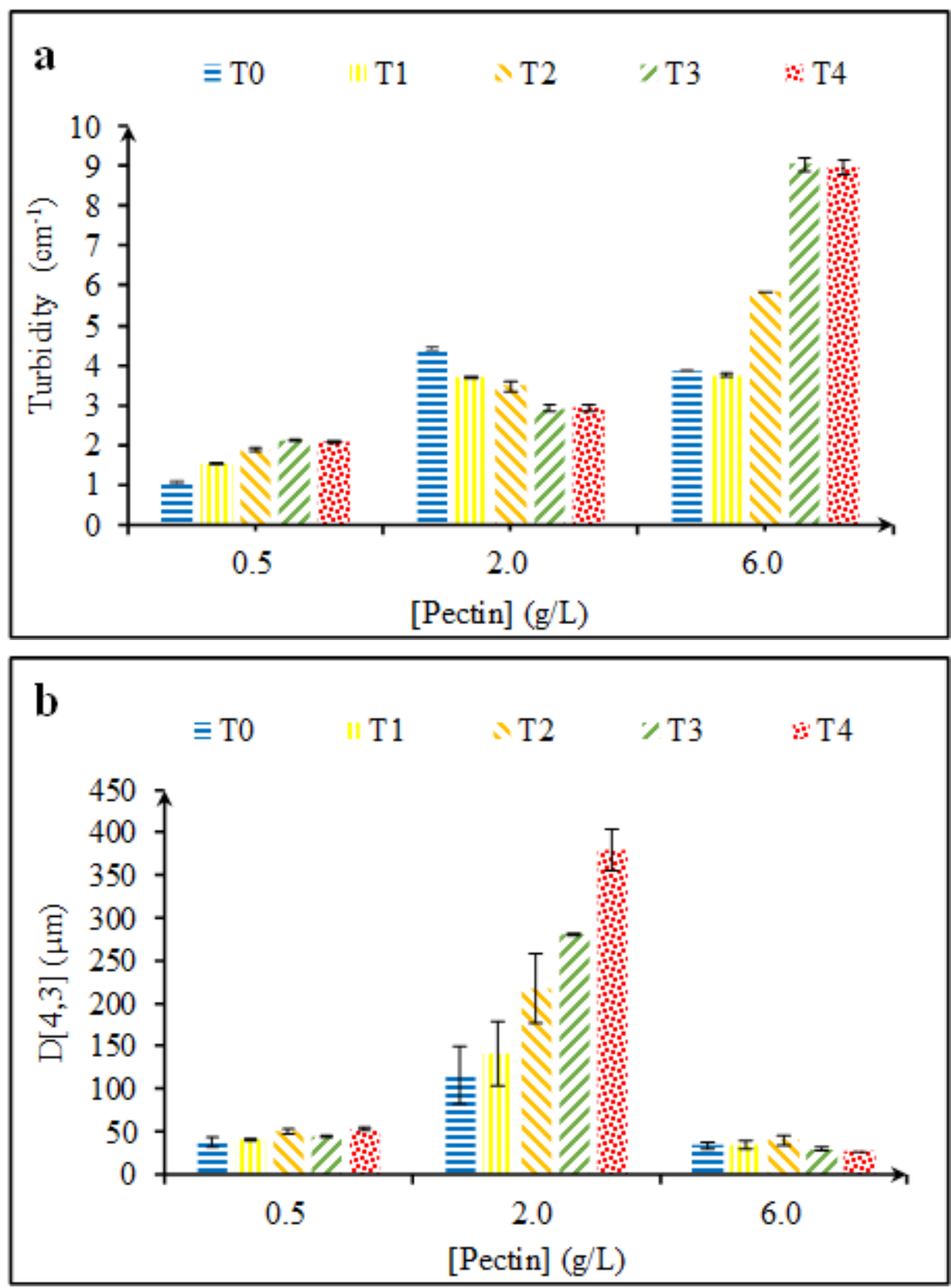


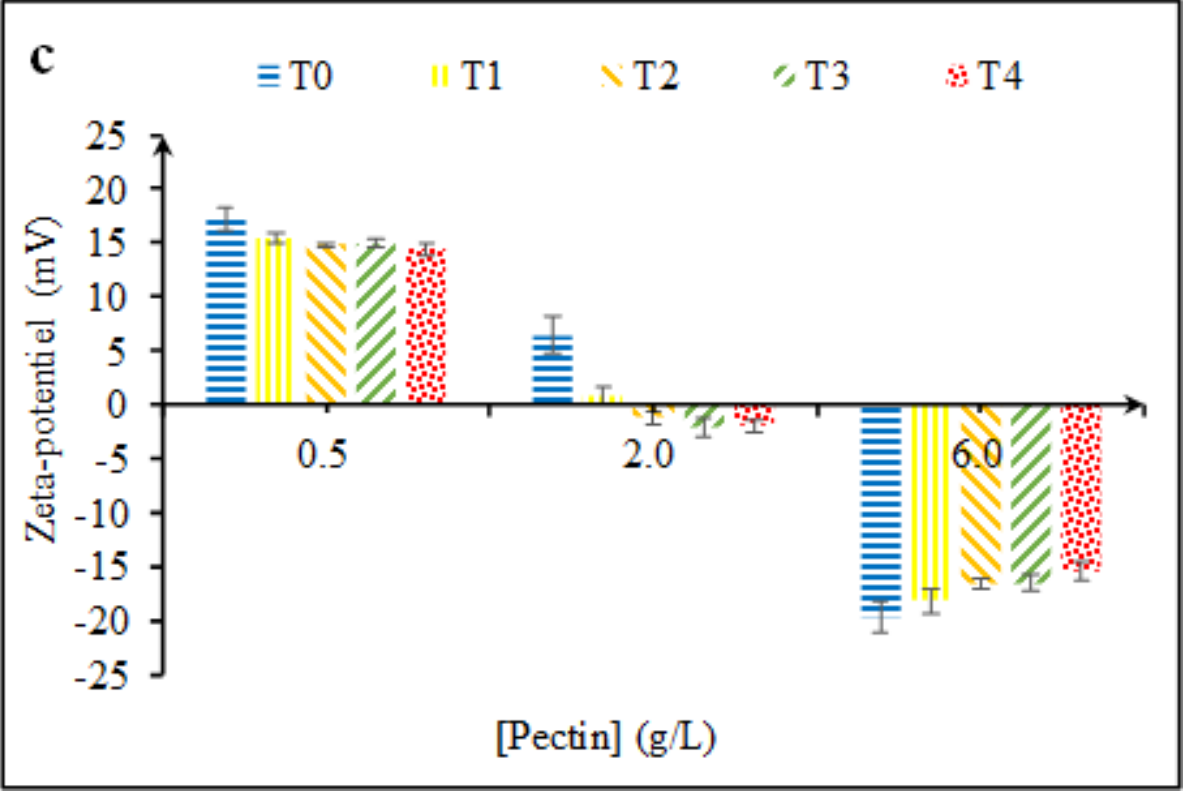

